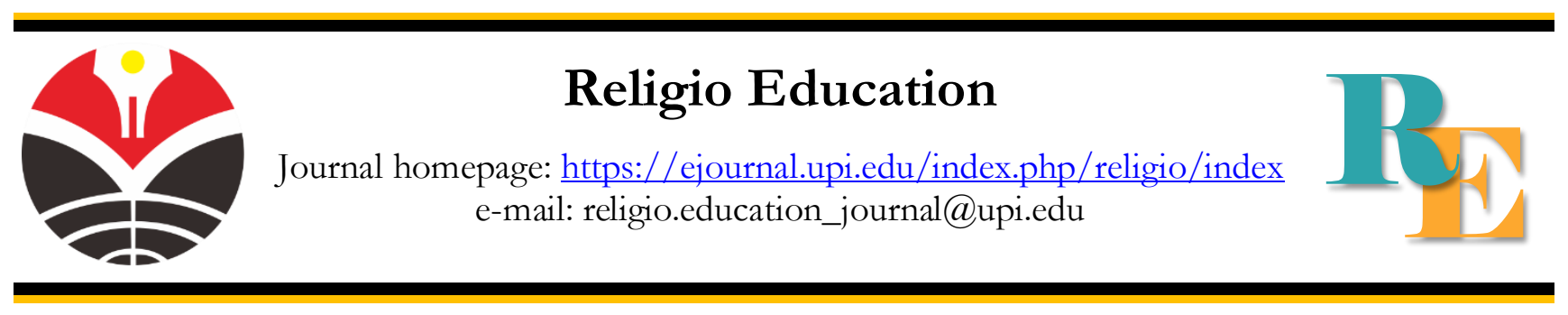

\title{
SECULARISM AND ISLAMOPHOBIA: \\ HISTORICAL RECONSTRUCTION OF THE FALL OF CHINA'S IDEOLOGY AND ECONOMY
}

\author{
Ku-Ares Tawandorloh* \\ Fatoni University, Khao Tum, Yarang District, Pattani, Thailand \\ kuares.t@ftu.ac.th \\ Ardareena Chema \\ Fatoni University, Khao Tum, Yarang District, Pattani, Thailand \\ adareena@ftu.ac.th \\ Kamaludin \\ Al Azhar University of Cairo, Mesir \\ kamaludin00@gmail.com \\ *Correspondence: kuares.t@ftu.ac.th
}

\section{A b s t r a c t s}

Islamophobia is an issue raised by Islamic antagonist groups to portray Islam as a radical, anarchist and primitive religion. Secularism is a thought product with the concept of separating religion and the world, which is being forced to become an ideology that is accepted internationally. China, as an influential economic country in the world, provides penetration with its economic strength so that ideas that are contrary to Islamic principles dominate global ideologies. No matter how great an ideology is, it turns out to have a fragility, this is what the Chinese State has forgotten. Success in the economic field has in fact caused problems in various sectors. This article presents the historical facts of how the fall of China's power was due to over-imposing an ideology that contradicts the holy Islamic shari'ab. The research method used in this research is descriptive analysis method. The research data were collected from various sources, then analyzed using the literature review technique. The results showed that the influence of cultural values, selfishness, high nationalism culture accompanied by the political heat of the country, became a barrier for Chinese people to accept the values of the spirit of faith contained in Islamic teachings.
Article Info

\author{
Article History: \\ Received 17 Jan 2021 \\ Revised 10 Feb 2021 \\ Accepted 03 Apr 2021 \\ Available online 15 Mei 2021
}

\section{Keyword: \\ China; \\ Economy; \\ Ideology; \\ Islamophobia; \\ Secularism}




\section{Introduction}

Islam is the main religion that regulates and teaches how to form worship, sharia and interaction (Nasuha 2009) which is oriented to the benefit and happiness of earthly and ukhrawi life, ritual and social, as well as the lives of individuals and worshipers (Turmudi 2017); (Zuhdi 2017) this is based on the fact that Islam was revealed to affirm that its teachings are universal in nature by carrying out the vision of rahmatan lil alamin, or good for all humanity, nature and the environment (Rasyid 2016); (Luthfi 2017); (Zuhdi 2017); (Asmani 2017) which has a positive, inclusive, comprehensive and holistic impact on human life (Mucharomah 2017) or a perfect idea without weaknesses and deficiencies, sacred and authentic ideas that originate from divine revelation (Rasyid 2016) which is always relevant throughout all time and everywhere (salih li kulli zaman wa makan) (Masduqi 2013) which is manifested in the form of attitudes and behaviour based on Islamic values to direct the basic potential (fitrab) of humans in achieving happiness in life in the world and the hereafter (Parhan et al. 2020).

As a universal religion, Islamic shari'ah deserves to be applied and applied in every era and place (Yūsuf al-Qordowi 2007). There is no time limit on the application of Islamic sharia because Rasulullah SAW was sent as Rahmatan Lil Alamin's messenger, this is in line with the QS. Al-Anbiya (21): 107. This verse is a sign that happiness in the world and the hereafter must be reached through faith in Allah and accepting his shariah. Among the values contained in Islamic principles are universality, diversity, consistency, and absolute servitude to God.

Islam commands its people to always put forward a balance in everything, including achieving success not only world-oriented but also includes the success of the hereafter. Today, people have been wrong in understanding the paradigm related to wealth. The issue arises that applying sharia in economic activity will cause setbacks and primitives. For them, success must be achieved by justifying any means even if they have to collide with Islamic rules (Al-Madani 2002). Whereas Islamic teachings emphasize the principle of balance in all aspects, this gesture is shown by the Prophet when praying, that is, asking for good in the world and the faith.

Islamophobia is an attitude that shows intolerance towards religion in general and excessive fear of the presence of religion in public spaces (López 2011). The same thing was stated by (Erik 2012) who said that islamphobia is a form of intolerance towards religious people, which is a new form of racism or cultural racism (Modood 1997). More specifically expressed (Rana 2007) who said that fear and hatred was towards Islam and Muslims, here clearly there is a form of discrimination and intolerance towards Muslims around the world, which is actualized through actions and treatment in the public room, clearly this is an attitude of racism.

Today, China is a country that can cut the distance of economic acceleration so quickly with superpowers like the United States. Rapid economic growth can boost the country's foreign exchange income so that it impacts on the welfare and security of its people. Some research, which was carried out by several world institutions, stated that China had shifted the US as the second-largest exporter in the world, and it was predicted that in 2010 it would take first place from Germany. Also, the country's foreign exchange reserves are the largest in the world estimated at more than $\$ 1$ trillion. In 2006, China was the second-largest economist after the US, and it is estimated that by 2050 it will be number one in the world (Ramli 2019).

International media even issued several statements in which the statement led to the prediction of the State of China will become the largest economic power in the future to defeat the United States. Achievements achieved in a relatively short period not much to make the public wonder. The main factor that helped realize this achievement was how cultural values that had crystallized for thousands of years could be applied by the Chinese people in all elements of the layer. The culture that was born from the teachings of Confucius included polite, 
generous, sincere, diligent, and kind-hearted able to run well in every activity. So no wonder, if the Chinese people can work better and longer than workers from other countries.

In 2006, China had a surplus of the largest bank deposits in the world which reached nearly $\$ 180$ billion. Such great value is certainly not the result of a short effort, but for the hard work that has been proceeding and transforming for hundreds or even thousands of years. The penetration of Chinese companies has even gripped the economy in several parts of Southeast Asia. The principle of hard work and unrelenting united by doing anything to achieve dreams is a catalyst for the realization of China's superiority in conquering the world economy. China is a country that has an ideology contrary to Islamic values. The state of China today is based on the ideology of communism. Where the main substance of the content of his teachings is not to believe in the existence of God. Communists think God does not exist. Therefore they assume that their success will depend on the results of their hard work. Then, one of the communist doctrines is a continuous revolution. The revolution spread throughout the world, so communism is often called go international.

With its economic strength, China is trying to force its country's ideology to be accepted internationally. Various attempts were made to campaign for this mission, one of which is how to image and position the teachings of Islam as teachings that are loaded with radical, anarchist, and primitive values. The use of mass media is considered a powerful weapon to smooth the negative campaign. Also, acts of discrimination were carried out by the Chinese government against ethnic Uighurs in the Xin Jiang region. As great as any ideology has fragility and shortcomings. Even inclined to necessity. There is no eternal ideology other than the teachings revealed by God, the teachings of Islam. This is what the Chinese government has forgotten. No matter how great they are in achieving success in the economic field, in fact leaving a large gap that ends in disasters in various important sectors. Ecology and the environment are the worst impacts of this cruel ideology.

Historical fact notes, when a nation is far from religious teachings and norms, ignoring the environment, ignorance of the deviations that arise during society, will invite adzab and disaster that comes to them (Moordiningsih 2015). The Qur'an emphasizes how the destruction of previous nations whose ideology is contradictory to Islamic teachings. The nation of Noah was drowned in a terrible flood QS. Al-Ankabut (29): 14 (Jum'ah 2012) Then the greatness and valor of Pharaoh with his armies were helpless before God, so they were submerged into the sea (Al-Qurtubi 1964). In QS. Fushilat (41): 15, Allah destroys the Ad with a cold cyclone that destroys. Likewise, the Thamud, the Prophets of Syuaib (as) were destroyed by the earthquake Qs. Al-A'raf (7): 78 (Thanthawi 1987) Among the factors that caused the previous nations to be punished by Allah SW'T were acts of sin, cruelty, rejecting truth, ungodliness, doing damage both in the form of ideology and action (As- Suyūti, 2003).

This article tries to present a portrait of how the State of China as the most influential economic country in the world whose ideology of communism tries to transform from an ordinary country to the most influential country in the world, especially in the economic sector. The noble cultural value of the inheritance can transform the State of China as a superpower in the world. But progress in the economic field was not achieved by harmony with religious values there were deviant practices practiced by the Chinese nation. The discrepancy between the teachings of Islam and the teachings of Communism in China plus culture that has been deeply rooted from time to time is strongly suspected as one of the factors of rejection of Islam (islamophobia). In the end, the distance of religious values is one cause of the entry of China into the abyss of destruction that might not have been predicted. 


\section{Methods}

The research method used in this research is a descriptive analysis method. The research data were collected from various sources, then analyzed using the literature review technique.

\section{Results and Discussion \\ Chinese History and Cultural Values}

Chinese culture is the longest-told culture on earth. The Chinese writing system, as old as 4000 years, was discovered by archeologists, starting with writing carved on the bone (Fanga et al. 2013). The first imperial dynasty system in China was the Qin dynasty founded by Qin Shi Huang in 221 BC. Later it was replaced by the Han Dynasty which lasted 423 years. During this period China had great achievements in natural sciences and mathematics, for example, the discovery of the water clock and compass and achievement in the economic field. Then in 618, the Tang Dynasty was formed, during this time a comprehensive political system was used and government officials were selected based on good service and academic background. The Tang period marked the beginning of technological advances in China, such as printing technology, improvements in papermaking, and the invention of gunpowder (Tang, Li, and Wang 2011).

The Tang Dynasty ended in $907 \mathrm{AD}$ and was subsequently taken over by the Sung Dynasty in 960 AD for more than three hundred years. During the Sung dynasty, landscape painting was considered the highest art form. The Sung Dynasty is also famous for its pottery and porcelain. At the end of the Tang period and the beginning of the Sung Dynasty, the emphasis on Confucianism became dominant again. It was during this period that elements of Confucianism, Buddhism, and Taoism were integrated into Neo-Confucianism. The Sung Dynasty ended in $1279 \mathrm{AD}$ for the next 19 years, the Mongols controlled China. The Mongol nation was the first foreign invaders to hold the government of the Khan family, especially Kublai Khan (Genghis Khan's grandson), China was once again reunited and Beijing was made the capital. The Mongols refused to use Chinese culture instead to use their language and traditions. In the 14th century, the Chinese destroyed the Mongol dynasty and restored Chinese rule.

During the next 276 years of the Ming Dynasty (1368-1644), there were no breakthroughs or major contributions, either in science or art. By the last century of the Ming Dynasty, many internal and external problems had to be faced, such as corruption and the threat of invasion by Mongols and Chinese rebels. Manchus was subsequently invited by the Ming emperor to crush the Chinese rebels and after that Manchus continued to support and establish the Qing dynasty (1644-1911). Some important events occurred during the Qing dynasty. The events were Opium Wars (1839-1860), Taiping Heavenly Kingdom (1851-1864), and Boxer Rebellion (1900). The Qing Dynasty fell in 1911 and China was taken over by revolutionaries - the National party under the leadership of Sun Yat Sen. The communist party emerged in 1921 and a civil war between the National Party and the Communist Party lasted from 1927 to 1936. Japan invaded China in 1937 which triggered an anti-Japanese war until 1945. Finally, the People's Republic of China was founded in 1949. Under this Historical chronology China.

Confucian culture as a common factor is also a catalyst underlying the effectiveness of Chinese ethnic groups in Southeast Asia (Levinson and Rodebaugh 2013). In line with the study, a study published their findings from an empirical study. The research shows a significant relationship between the level of economic development in many Southeast Asian countries that have just become industrial countries (Hong Kong, Singapore, South Korea, and Taiwan) with Confucian Dynamics, some of which are Confucian ethics about being economical, diligent, developing oneself, harmony, and respect for heredity and how this relationship contributed to capitalist development (Franke, R., Hofstede, G., \& Bond 1991). 
Table. 1.1

Summary of Chinese History

\begin{tabular}{ccc}
\hline Old in unit Years & Years & Dinasti \\
\hline 500 & $2100-1600 \mathrm{SM}$ & Xia \\
500 & $1600-1100 \mathrm{SM}$ & Shang \\
330 & $1100-771 \mathrm{SM}$ & Western Zhou \\
550 & $770-221 \mathrm{SM}$ & Eastern Zhou, Spring \& Autumn \\
& & Period \\
14 & $221-207 \mathrm{SM}$ & Qin (First Emperor of China) \\
426 & $206 \mathrm{SM}-220 \mathrm{M}$ & Han-West and East \\
& $220-280 \mathrm{M}$ & (Western and Eastern) \\
60 & $265-420 \mathrm{M}$ & Three Kingdoms \\
155 & $420-581 \mathrm{M}$ & Jin-West and East \\
& & (Western and Eastern) \\
161 & $581-618 \mathrm{M}$ & North and South \\
& $618-907 \mathrm{M}$ & (Northeern and Southern) \\
37 & $907-960 \mathrm{M}$ & Sui \\
289 & $960-1279 \mathrm{M}$ & Tang \\
53 & & Five Dynasties (Five Dynasties) \\
319 & $916-1125 \mathrm{M}$ & North and South Sung \\
& $1115-1234 \mathrm{M}$ & (Northeern and Southern) \\
119 & $1279-1368 \mathrm{M}$ & Liao \\
90 & $1368-1644 \mathrm{M}$ & Jin \\
276 & $1644-1911 \mathrm{M}$ & Yuan (Mongolian) \\
37 & $1912-1949 \mathrm{M}$ & Ming \\
& & Qing (Manchuarian) \\
& & Republic of China \\
& & People's Republic of China \\
& & People' Republic of China) \\
\hline
\end{tabular}

Chinese culture that has developed for more than 2500 years was initially influenced by three forming forces: Confucianism, Taoism, and Buddhism. These three forces that have formed have produced a culture of humanism that has made the Chinese lifestyle very practical and also in difficult situations. For example, in 4000 years of Chinese his tory, thousands of wars have been fought but none have been caused by religious strife. These three teachings praise each other rather than contradict each other.

The main characteristics of Confucius teaching consist of two components: the principle of humanism includes polite, generous, sincere, diligent, and kind. Confucius believes that by applying humanitarian practices that people can continually be called 'high-quality' or 'respectable humans'. Associated with logical principles and not excessive, for Confucius, it is important for humans to balance words with their actions. The parallel to the Confucianism movement is the teachings of Taoism supported by Lao Tzu. Taoism lessons are more metaphysical and abstract than Confucianism, in that Taoism teaching involves how something is served and how it works. In short, Tao is the principle underlying all creation. Buddhism originated in India, this ideology being the only foreign influence that entered deeply into the minds and lives of the Chinese people. Buddhism aims to guide the human race to peace by reducing or stopping suffering and developing good morals. The Buddha taught the 'Karma 
Doctrine' and the 'Path to Nirvana'. The doctrine of Karma which refers to rebirth comes from knowledge of one's previous life experiences. The path to Nirvana leads to the end of Universal suffering and the attainment of eternal happiness through spiritual understanding.

The real difference between the three forming forces is Confucianism which embraces the understanding of humanism (humanity), Taoism embraces the understanding of naturalism (the power of nature) while Buddhism adheres to the understanding of spiritualism (spirituality). These three teachings are not strictly religious in all attempts to understand life by using different metaphysical and epistemological. Because culture could change according to the new environment, during the 11th century the teachings of Taoism and Buddhism assimilated into Confucianism into a single entity that included all three, Neo-Confucian or Post-Confucianism. This teaching is a dominant system that remains a major influence in Chinese thinking. Lessons about Chinese cultural values can be briefly categorized into Social Structure, Kinship, Interpersonal Relations, and Basic Assumptions.

\section{Social Structure}

Confucius taught people to follow five basic human relations (wu-lun): between wife and husband, father and son, between siblings, government and citizens, and between friends, to maintain a stable society that produces a peaceful and orderly state. Based on the five basic human relations, self and family development continues to develop throughout the network of human relations that continues to expand towards a state of peace and order. Therefore traditional society develops with the family as a basic unit. According to Confucius:

If you want to make your house tidy, you have to develop your morality first; If you want to develop your morality, you must arrange your heart properly. To arrange your heart properly, you must be sincere.

\section{Kinship}

In family emphasis, 'a child's respectful attitude' ranks the most important rating system or concept in the development of each individual. When Tzu Yu asked about 'the respect of a child', Confucius answered: Today a pious son is only a person who keeps his parents able to eat. Even though dogs and horses are given food. If there is no respect, where is the difference?

As members of a family, the Chinese nation individually are less individualistic and tend to think less of society but are more family-oriented, family interests are placed far above individual interests. The emphasis on 'the respect of a child' is the foundation of the five fundamental relationships as well as the governing power of the Chinese vertical relationship (for example between father and son). In the Chinese family, getting offspring, especially sons, for the sake of parental honor and continuing 'surname', ranks highest in the task of fostering respect for Chinese descent.

The attitude of thinking about the family and endless efforts to make the 'family name' make the Chinese work diligently while still being thrifty to the family. In addition to the emphasis placed on vertical relationships, the Chinese are also expected to support horizontal relations between brothers and sisters. A brother or sister is expected to take care of even sacrifice for his younger sister.

\section{Interpersonal relationships}

Regarding relationships, the Chinese people placed a heavy emphasis on 'li', actions or good behavior. For young people, a child is taught to refrain from behaving aggressively in front of seniors or older people. Open conflict must be avoided at all costs or the severity of efforts made to maintain harmonious relations. 
In interpersonal relations, Chinese people prefer tolerance, harmony, trustworthiness, non-competition, and conservative attitude (maintaining traditional values) (Sheh, 1993). The tolerance which refers to a willingness to forgive mistakes drives the learning process. Harmony supports the advancement of interpersonal relationships while trustworthiness fosters longterm relationships. Non-competitive and conservative attitudes are presuppositions for nonaggressive and non-confrontational behavior that reinforces interpersonal relationships.

In addition, Chinese people tend to play 'face' to strengthen good relations. Although there is no direct translation for the word 'face', the concept of 'face' relates to one's credibility, self-esteem, and reputation. In Chinese society, the state of losing 'face' can be interpreted as losing credibility or reputation while achieving 'face' is a sign of honor or dignity. Therefore, the state of gaining or losing face can have a strong influence on individual behavior also in a business context.

The concept of 'face' and the importance of developing a family good reputation 'family and individual self-image have made Chinese individuals strive for good and gain public recognition. The orientation that an individual has towards others and a deep sense of enthusiasm for knowing how people judge them has made the Chinese community very 'critical' in their perspective (Myers, 1989).

\section{Basic Assumptions}

Regarding the relationship with nature, to a certain extent the Chinese people believe that fate is predetermined, as the Chinese call it 'God's Will'. For example, many Chinese people believe in 'feng shui' (geomancy) when designing their own office and home layout. Many Chinese also believe in fortune-telling. The Chinese see everything in the world in terms of interconnection and interdependence. No creature or object, whether it exists naturally or is made by humans, is created individually. Everything is interconnected through cause and effect. Therefore, everything depends on something else. For example in traditional Chinese medicine, although treatment is slower in terms of efficacy compared to Western medicine, China seeks to heal and improve overall patient health rather than focusing only on the injured part. They believe that the function of one part of the body and the problem of that part are closely related to the total of all parts of the body. Therefore, to get a permanent cure they use holistic.

Another basic assumption that distinguishes Chinese culture from other cultures is the concept of 'time'. For the Chinese, time is never defined as a straight line, so there is a beginning and an end. Time is always defined as a circle. The view that time is spinning also causes Chinese business people to view their derivatives as a form of continuity of life and business (Sheh, 1998). The Chinese people think that it is very important for someone to be respectful to their parents to get inheritance in the form of a family name and family wealth. Chinese businesspeople hope that their business can be passed on to their children or even grandchildren.

The Chinese define 'space' in terms of what can be concluded. For example, the value of a house is its land and building materials (brick, steel, tile, etc.), but its use is emptiness or 'space' created by four walls. Similarly, a good Chinese landscape painting should not fill the entire canvas with paint. Sufficient space must be available to allow connoisseurs of the painting to reflect and imagine (Sheh, 1998). Culture and wisdom are the most valuable things that our ancestors left us. Because the influence of culture spreads into every aspect of human culture and behavior, having the appropriate cultural values will certainly increase the effectiveness of practitioners. So it's entirely up to us whether we are wise enough to defend the wisdom of our ancestors through conscious learning and practice. 


\section{Principles of Chinese Communism}

The rise of China as one of the forces considered to replace the domination of America and Russia is certainly inseparable from the strategic policy of the Chinese people themselves in responding to existing trends. People often wonder why China is a communist country. If we remember that the ideology of communism was the most modern ideology at the time and that communism was a product of the West, it is understandable why Chinese intellectuals were so passionate about embracing it. The establishment of the Chinese Communist Party in 1921 must be understood as a strategy. Strategies to defeat the West with Western tools (Wibowo, 2004: 217).

Changes in China's foreign policy also always change from time to time according to their needs. The ability of Chinese leaders who are always responsive in responding to international change greatly influences their foreign policy. But the most dominant thing in the change of foreign policy is the situation in the country which greatly influences his behavior in the international world. This is in line with what is delivered by Sukma (1955: 12) that on the other hand, changes in the international and/or internal environment will also bring changes to the world picture, situation definition, and in turn, will also affect a country's foreign policy.

Historical experience as stated above has quite a strong influence on the awareness of modern Chinese leaders (Post-Revolution of 1911). This awareness was not only among Communist leaders but also among Chinese Nationalist (Guomingdan) leaders. Sun Yat-Sen, the founder of China Republic, views China "as the poorest and weakest country in the world; the people of other countries prepare knives and forks while China becomes their fish and meat "(Price, 1932: 39). Therefore, Sun reminded that the rise of China was not only great power but also able to transfer Chinese values to the whole world.

Communist Chinese leaders also have a high awareness of the grandeur and bitterness of China's past history. The assumption of the lost territories shows that the conception of the "Middle Kingdom" is firmly embedded in the thinking of Communist Chinese leaders. Although traditional elements have a strong influence, how Communist China sees the world is very much determined by Chinese elements of communism. These elements of communism that are uniquely Chinese, especially the ideas of Mao (Mao Sixiang) combined with Chinese historical and cultural roots form the image of the Communist China world.

\section{The revival of Chinese Economic Power}

The process of China's economic power rebound in the global world can not be separated from the right strategies in exploiting opportunities and opportunities. The combination of cheap labor and modern factories really made China able to compete and that competitiveness attracted the enormous investors needed to carry out the process of urbanization. However, that is not the only force behind growing hunger, another force is the development of infrastructure, China is reinventing itself to resemble the image of its master teacher, the United States but on a broader and faster scale.

The destruction of the German steel giant, the ThyssenKrupp Steel Factory in Dortmund employed around 10,000 employees. The production process of making iron and steel in this company has been running for around 200 years. The Horde and Westfalehnthutte people who live in parts of the Ruhr Valley supply Prussia, cannons, tanks, casings, and armor for warships. The cause of the collapse of the steel mill was the slow but sure result of defeat in competitiveness. In the early 1990s, when South Korea's efficient steel mills sold steel to the world at lower prices, Horde steelworkers demonstrated to reject 35 hours of work a week. Then the reunification of East and West Germany demanded its victims by forcing the government to raise taxes and become an obstacle to general economic activity. In the mid1990s, the fate of the Horde factory became a contentious issue. First, management reacts as 
management in general; they discussed a merger with one competitor to obtain operational synergies, reduced costs, and better competitiveness, but by the year 2000, when world steel prices fell, all talk of an effort to save the factory was dashed. It seems that not much can be done.

Then the Shagang company from China came up with a new mission, they acquired the German company. The effort is to reconstruct the mouth of the Yangtze River. The first action was the arrival of the invasion of thousands of Chinese workers to dismantle the factory equipment. At the end of 2002, in less than a year, China had completed the demolition work, a year earlier than the schedule they had agreed with ThyssenKrupp and two years earlier than originally predicted by the German company. The workers work diligently and tenaciously. They sleep in a dormitory and work twelve hours a day during the summer, seven days a week. The perseverance of Chinese workers speeds up the transfer process.

The move of the largest steel mill to China, making Horde one of the earliest communities on earth to feel the power of China's rising shocks. There is even a saying that is said by Napoleon Bonaparte:

"Let China sleep. Because, if China wakes up, it will shake the world "

The Chinese economy recorded an annual growth rate of 9.4 percent, the highest of any large economy in the world. By 2005, in China, around 350 million people had mobile telephones and more than 100 million people accessed the internet, whereas, in 1978, almost no one had a personal telephone.

Shagang the "Steel Sand", Shen, one of the directors when asked about his policy of buying the company, he said:

"I need a horse that runs fast and doesn't eat a lot of hay! when world steel prices fall again, and that will inevitably happen in the next few years, many of our competitors who have bought expensive new equipment from abroad will go bankrupt or be depressed because they are full of debt so they cannot move. At that time, you will see that our purchase is a good decision. "

Shagang bought the steel mill in scrap metal prices: \$24 Million. It's land and sea membership from Dortmund has cost $\$ 12$ million and its reconstruction (plus the purchase of 1.5 square kilometers of land) costs another $\$ 1.2$ billion. In total, about $60 \%$ of the cost of purchasing a new factory, and by reconfiguring, Shen believes he can increase annual production by 3 million tons more than when the factory was operated by Germans in Dortmund. If the plant starts production at full speed, its capacity will more than double Shagang's current capacity, and this will jump the company to the rank of twenty world steel producers.

If Shagang had decided to buy a new factory, it would not only cost much more but also take three years to make it and one or two years to assemble it. Shen's strategy is very telling, wherein his distant vision, he sees that even though steel prices around the world were plummeting in 2001, demand in China will soar in the next two or three years. and in the following years, the Shen Factory supplied steel to Volkswagen, a car manufacturer. The important price of the steel mill's story portrays that Shen managed to lift himself out of poverty and without ever getting any business education, was able to run one of the most competitive steel companies in the world.

The second story is how Deng a visionary improvised by conducting a Cultural Revolution. He recruited Chen Yun, an expert in overcoming the economic crisis, to think of new strategies. Chen assumed that the productivity of the farmers, who at that time numbered around 700 million of the total Chinese population of 1.1 billion, had been suppressed too long under the communal farming system institutionalized by Mao. From 1979 onwards, farmers could form smaller 'workgroups' to work on a predetermined division of land, and harvest the 
profits or losses from their harvest. However, a key principle of the new policy is that the working groups may not consist of one family and the land they are working on remains the property of the State. However, in one of the first important acts of creative defiance, farmers used the new policy to start cultivating family land. Local officials knew exactly what was happening, but they also saw that the productivity of the poor farmers had freed and that it made the weaknesses of the communal system a thing of the past. The impact was immediately felt, towards 1984, the national grain harvest rose to 407 million tons from 305 million tons in 1978, and the meat was more evenly available.

New tycoons emerged, one of which was Mou Qizhong, who emerged from prison without a job, or a real prospect. He took a loan to start a business selling brass ornate alarm clock to shops in Shanghai and made a decent profit. Then a great opportunity came: he heard that the local airline, Sichuan Airlines, needed an airplane but did not have the cash to buy it. He knew that the Soviet Union had many airplanes but lacked finished goods. So, he brokered the transaction, 500 railroad cars filled with instant noodles, shoes, clothing, and other items were exchanged for four Soviet passenger planes. The courage of this 'socks exchanged by jet' transaction is pleasing to Beijing, who hails Mou as one of the 'ten best private entrepreneurs'.

There was Liu Yonghau who in 2005 was the largest individual shareholder in China Minsheng Bank, the first private bank in the country, in the 1980s, using a small amount of money borrowed from relatives, began raising chickens on his balcony. Chickens lay eggs, eggs make more chickens and through various processes eventually, Liu became the leader of New Hope, the largest animal feed group in China. He used the money obtained from the business to buy shares in Minsheng, which is now listed on the stock market.

Lu Guanqiu owned a Wanxiang company that was so successful in 2005 that it was able to make parts for General Motors. In the mid-1980s, he only started his business by bolting compasses in his dirty iron workshop. Li Shufu, the founder of Geely, a private car manufacturer that in 2005 beat sales of some of the world's most famous brands, when Meng sold noodles, started a business by simply assembling a refrigerator using spare parts purchased with a loan of 2000 renminbi (RMB) from his father. Li Dongsheng, who in 2003 acquired Thomson, a French electronics company, for TCL, a manufacturer of electronics and private household appliances, spent most of his time in the 1980s producing electronic magnetic tapes with a Hong Kong businessman at the back of the farm machinery warehouse. Zong Qinghou is the owner of the Wahaha group which in 2005 turned into a major competitor to Coca-Cola in China. In the 1980s, he sold ice cream (only ice, without milk) on the street at a price of less than one US cent.

\section{Principle of Allowing All Methods}

In the mid-1990s, piracy became a very common phenomenon. After infecting the industry, the phenomenon spread like a virus and became endemic to the value chain and jumped from one company to another. Predictions suggest that American, Japanese, and European companies could have lost more than $\$ 60$ billion a year due to Chinese piracy (Fanga et al. 2013). The total suspicion of Western companies due to theft of intellectual property rights is equal to more than the total flow of foreign direct investment into China in 2004 where foreign investment came in at $\$ 56$ billion. Some theft is done systematically, almost every time there is a Hollywood film that is a big success, the DVD will appear in China before it is launched in the same format in America.

In the field of publishing, a series of how-to business books by Paul Thomas, a Harvard Business School professor, became one of the targets of this strategy, some publishers had more than 100 fake book titles on the market in early 2005. Likewise, other counterfeit goods are phenomena tragic or funny, like golf clubs, electric transformers, drugs, brake pedals, and 
others. But the worse problem for foreign companies is the problem where China is trying to offer counterfeit goods with the equivalent quality of the original goods, such as cases of violations that occurred in the car industry, Chery Automobile Company in the 1990s.

However, the commercial impact of piracy is always the same: rapid destruction of value on a variety of finished products. This applies not only to established products but also to new technologies, and evidence of a continuing decline can be found in both single instances and overall prices. 29-inch flat-screen televisions, which were sold at 6000 renminbi in 1998, fell to under 2000 renminbi at the end of 2004. Mobile phones with color screens were priced at 6500 RMB in 2001, at the end of 2004, they were below 2000 RMB (Law and Ho 2009). Unreasonable prices also contributed to the destruction of the global economic system by the State of China.

In the field of technology, the theft of "intellectual property rights" looks thick. The rise of China's technology is supported more by trade rather than research. In general, Chinese companies obtain their technologies by buying, copying, or convincing foreign partners to transfer as part of the price to gain access to a large potential market. In this context, the driving force behind China's revival as a technological power is globalization, not research and development. The tempting lure of a 1.3 billion market, though it might be an illusion, has helped China to jump over some technological hurdles that bind the economies of several other countries.

Weak legislation bridges the rampant practice of corporate corruption scandals. The company named Zhengzhou Baiwen is run by Li Fuqian where the shopping center and distribution company is chosen to be a registered company even though this shop does not meet the requirements, one of which is that it must provide benefits. A little lie was needed, but $\mathrm{Li}$ and his colleagues decided to give a big lie - they claimed that the company's profits had increased thirty-six times in the ten years before the store bounced in 1996. When the figures were announced, the public investors responded, and Baiwen's share price soared. But not long after that, the company fell, and $\mathrm{Li}$ was arrested and thrown in jail and subjected to heavy fines.

As a result of the disclosure of the scandalous practice, triggering the stock market to rock repeatedly. In 2001 the CSRC found forty other companies that had falsified data on their results, including a company called Yingu-angxia that had falsified profits of nearly $\$ 100$ million. Another thing that adds to the destruction of their economic system is that the practice of abuse of administrative power to enrich themselves and their cronies has become commonplace.

\section{The Catastrophe of "Pseudo" Success}

Chinese cultural values are often seen as important factors in determining and shaping the managerial and organizational practices of Chinese business. The influence of Chinese culture on managerial practice is so great that it creates different characteristics in the Chinese managerial system (Redding, 1982). Continuous efforts in developing family wealth and the veneration of ancestors made Chinese national leaders work diligently and live frugally for the sake of the family (Thong, 1987). In line with this, the practice of prioritizing the interests of groups with a high sense of togetherness in the Chinese hierarchical system (Mun, 1986).

The era of communism in China is not environmentally friendly. The combination of indifference, too large a population, frivolous industrialization, and the failure of a planned economic system in which prices are determined by the State to determine accurate prices for natural gifts have caused multidimensional crises, especially an incomparable environmental crisis. The waterways which were only ten years ago were rivers that flowed swiftly have now slowed down to splashing water or are completely gone. Food is often contaminated with animal hormones and agricultural chemicals with dangerous and illegal levels. New and strange 
diseases such as SARS and bird flu occur regularly. Air pollution is so bad that 380,000 people might die prematurely due to respiratory diseases every year when we arrive in 2010. Of the list of the twenty most polluted cities in the world, sixteen of them are in China, Acid rain fell by more than 30 percent in this region. In a study conducted by Daniel Jacob, a professor of atmospheric chemistry from Harvard, tracking dirty air ridges at a point above New England, samples showed that the pollution originated in China.

Some species of animals and birds become rare or lose their habitat because the wetlands and forests have disappeared. Some small and large cities such as Pingxiang began to sink into underground holes that had been dug by miners or because of the depletion of groundwater that was once there. The splendor of the hard-built State of China turned out to save a fragile ecological foundation. Bear and small rivers have dried up throughout northern China and the depth of water sources has fallen rapidly as wells, many of which are illegally dug, have increasingly subsided into deeper groundwater supplies. In all, about 400 of China's 668 major cities are short of water and water rationing measures are increasing.

Oil is one of the basic needs of the State of China. During the 20th century, the US was able to supply fuel for its development with oil extracted from mines in Alaska, the Gulf states of the Gulf, Oklahoma, off the coast of Louisiana, California, and Illinois. However, China's geology is not that rich. Many sources were discovered by China during the 1960s and 1970s but in the last two decades, production has dropped too far lower than the needs of its own country. Twenty years ago, China was the largest oil exporter in East Asia, now China has become the second-largest oil importer in the world. In 2004, China posted around 31 percent in the increase in world oil demand, so that the increase in oil prices to above $\$ 60$ per barrel in mid-2005 was arguably caused by high Chinese demand.

The main catalyst behind China's huge appetite is the imbalance between its population and the resources it has. Other causes are wasteful exploitation for decades and a lack of environmental awareness that characterizes the Communism era. China's dependence on foreign oil is due to its carelessness in exploiting uncontrolled oil fields.

\section{Conclusion}

Chinese culture is influenced by three ideological forces: Confucianism, Taoism, and Buddhism. The three forces that shape this have produced a culture of humanism that makes the Chinese lifestyle very practical and also when in difficult situations. The main characteristics of Confucius's teachings consist of two components: the principle of humanism includes being polite, generous, sincere, diligent, and kind. These cultural values have an indirect influence on China's style and way of playing in order to realize its vision of becoming the most influential country in the world, especially in the economic sector in the future.

In recent years, the rise of the Chinese economy has shaken the entire world. In just a short time, thousands of companies in Europe, Asia, and America fell victim to the Chinese trade invasion. Having workers who are reliable, resilient, and diligent is one of the keys to the success of China's economic transformation. Plus the abnormal price competition, making China a country with the aim of the main business partners for international countries. However, progress in the economy seems not to have been followed by progress in other aspects. Environmental aspects are areas that feel the effects of severe damage from the consequences of economic progress. Damage to the environment, compounded by the loss of religious norm values in smoothing out its mission, corrupt practices have run rampant, justifying all means done in every effort to smooth out its mission.

China today is a country that holds fast to the principles of communism in its philosophical state. The ideology, at least clashes with the teachings and values held by Islam. This ideological conflict turned out to have an impact on the perspective of the Chinese people 
in positioning Islam. Islamophobia or worry about Islam is at least influenced by certain factors, including the strength of Chinese cultural values, selfishness, high nationalism culture accompanied by the political heat in his country. This is according to the author's analysis as a barrier for Chinese people to accept the spiritual values contained in the teachings of Islam.

\section{References \\ Books}

Al-Madan̄̄, Izdihār Mahmūd Shābir. 2002. Ahkām Tajmīl An-Nisā Fi As-Syarìah Al-Islämiyyah. Riyadh: Dal Al-Fadilah.

Al-Qurtubi. 1964. Al-Jami' Li Abkam Al-Quran. Beirut: Dar Ihya At Turats Al 'Arabi.

As-Suyūti, 'Abdurraḥmān bin Abū Bakar. 2003. Ad-Dar al-Manthūr Fì at-Tafsìr bi al-Ma'thūr. Mesir: Dār Ḥajar Lil Buhūts

Mun, Kin-Chock. 1986. "Characteristics of Chinese Management: An Exploratory Studies". Dalam The Enterprise and Management in East Asia.

Redding, S.Gordon. 1982. "Cultural Effect on the Marketing Process in Southeast Asia". Journal of Market Research Society, 24:2:98-114.

Sheh, S.W. 1993. "Chinese Values and Organizational Practices: Singapore and Malaysia". Thesis. National University of Singapore.

Thong, Tin Sin Gregory. Mei 1987. "The Management of Chinese Small Business Entreprises in Malaysia". Asia Pacific Journal of Management, 4;3 pp 178-186.

Wibowo, I. 2004. Learning from China: How China Seizes Opportunities in the Era of Globalization. Jakarta: PT Kompas Media Nusantara

\section{Journal}

Asmani, Jamal Mamur. 2017. "Rekonstruksi Teologi Radikalisme Di Indonesia, Menuju Islam Rahmatan Lil Alamin." Wahana Akademika: Jurnal Studi Islam Dan Sosial 4(1):1-17. doi: 10.21580/wa.v4i1.1475.

Erik, B. 2012. "Defining and Researching Islamophobia." Middle East Studies Association of North America (MESA) Is Collaborating with JSTOR to Digitize, Preserve and Extend Access to Review of Middle East Studies 46(2):180-89. doi: https://doi.org/10.1017/s0026318400054146.

Fanga, Yi-ping, Jie Fanb, Mao-ying Shenc, and Meng-qiang Song. 2013. "Ity of Livelihood Strategy to Livelihood Capital in Mountain Areas: Empirical Analysis Based on Different Settlements in the Upper Reaches of the Minjiang River, China." Ecological Indicators 38(2):225-35. doi: https://doi.org/10.1016/j.ecolind.2013.11.007.

Franke, R., Hofstede, G., \& Bond, M. 1991. "Cultural Roots of Economic Performance: A Research Note.” Strategic Management Journal 12(1):165-73.

Jum’ah, Ali. 2012. Al-Madkhal Ilā Dirāsah Al-Madæāhib Al-Fiqhìyah. Beirut: Dār as-Salām.

Law, Wing Wah, and Wai Chung Ho. 2009. "Globalization, Values Education, and School Music Education in China." Journal of Curriculum Studies 41(4):501-20. doi: 10.1080/00220270802372329.

Levinson, Cheri A., and Thomas L. Rodebaugh. 2013. "Anxiety, Self-Discrepancy, and Regulatory Focus Theory: Acculturation Matters." Anxiety, Stress and Coping 26(2):171-86. doi: 10.1080/10615806.2012.659728. 
López, Fernando Bravo. 2011. "Towards a Definition of Islamophobia: Approximations of the Early Twentieth Century." Ethnic and Racial Studies 34(4):556-73. doi: 10.1080/01419870.2010.528440.

Luthfi, Khabibi Muhammad. 2017. "Islam Nusantara: Relasi Islam Dan Budaya Lokal." SHAHIH: Journal of Islamicate Multidisciplinary 1(1):1-18. doi: 10.22515/shahih.v1i1.53.

Masduqi, Irwan. 2013. "Deradikalisasi Pendidikan Islam Berbasis Khazanah Pesantren.” Jurnal Pendidikan Islam 2(1):1-20. doi: 10.14421/jpi.2013.21.1-20.

Modood, T. 1997. "Difference”, Cultural Racism and Anti-Racism', in P. Werbner and T. Modood (Eds), Debating Cultural Hybridity: Multi-Cultural Identities and the Politics of Anti-Racism, London and Atlantic Highlands. NJ: Zed Books.

Moordiningsih. 2015. "ISLAMOPHOBIA DAN STRATEGI MENGATASINYA." Buletin Psikologi 12(2):73-84. doi: 10.22146/bpsi.7470.

Mucharomah, Miftah. 2017. "Guru Di Era Milenial Dalam Bingkai Rahmatan Lil Alamin." Edukasia Islamika 2(2):172. doi: 10.28918/jei.v2i2.1667.

Myers, H. Ramen. Mei 29-31, 1989. "Confucianism and Economic Development: Mainland China. Hong Kong and Taiwan", dalam Conference on Confucianism and Economic Development in East Asia. Chung-Hwa Institution for Economic Research, 281-304

Nasuha, Chozin. 2009. “Konsep Islam Dalam Pemikiran ISIF.” Jurnal Islam Indonesia 1(1):1-8.

Parhan, Muhamad, Mohammad Rindu Fajar Islamy, Nurti Budiyanti, Risris Hari Nugraha, and Pandu Hyangsewu. 2020. "Responding to Islamophobia by Internalizing the Value of Islam Rahmatan Lil Alamin through Using the Media." Islam Realitas: Journal of Islamic and Social Studies 6(2):137-49. doi: http://dx.doi.org/10.30983/islam_realitas.v6i2.3695.

Ramli, Ramli. 2019. "Moderasi Beragama Bagi Minoritas Muslim Etnis Tionghoa Di Kota Makassar." KURIOSITAS: Media Komunikasi Sosial Dan Keagamaan 12(2):135-62. doi: 10.35905/kur.v12i2.1219.

Rana, Junaid. 2007. "The Story of Islamophobia." Souls 9(2):148-61. doi: 10.1080/10999940701382607.

Rasyid, Muhammad Makmun. 2016. "ISLAM RAHMATAN LIL ALAMIN PERSPEKTIF KH. HASYIM MUZADI." Epistemé: Jurnal Pengembangan Ilmu Keislaman 11(1):93-116. doi: 10.21274/epis.2016.11.1.93-116.

Tang, Guiyao, Ji Li, and Xinran Wang. 2011. "Multimarket Contact and Firm Performance: The Moderating Effect of Confucian Culture." Frontiers of Business Research in China 5(1):45-62. doi: 10.1007/s11782-011-0120-9.

Thanthawi, Muhammad Sayyid. 1987. “At-Tafsir Al-Wasith Lil Quran Al-Karim.” 516.

Turmudi, Muhammad. 2017. "Produksi Dalam Perspektif Ekonomi Islam.” ISLAMADINA XVI:37-56.

Yūsuf al-Qordowi. 2007. Ushül Al-'Amal Al-Khoir Fì Al-Islām Fi Dại an-Nuṣūs Wa Al-Maqāșid as-Syar'Iyyah. Cairo: Dār as-Syurūq.

Zuhdi, Muhammad Harfin. 2017. "Radikalisme Agama Dan Upaya Deradikalisasi Pemahaman Keagamaan." AKADEMIKA: Jurnal Pemikiran Islam 22(1):199-224. doi: https://doi.org/10.32332/akademika.v22i1. 